\title{
PENERAPAN POLA KO-MANAJEMEN DALAM PENGELOLAAN SUAKA PERIKANAN DI PERAIRAN UMUM
}

\author{
Zahri Nasution"), Emmy Dharyati"), Samuel"), Ondara") dan Agus Djoko Utomo"*)
}

\begin{abstract}
ABSTRAK
Suatu penelitian yang bertujuan melihat penerapan konsep ko-manajemen, yang merupakan suatu pengaturan kemitraan dengan menggunakan kemampuan dan minat masyarakat lokal, telah dilakukan pada dua reservat yaitu di Jambi dan Sumatera Selatan. Pengumpulan data primer dilakukan melalui dilengkapi dengan panduan daftar pertanyaan sesuai dengan tujuan penelitian. Data dikumpulkan dari responden nelayan, kelembagaan terkait dan laporan instansi terkait dan selanjutnya dianalisis secara deskriftif. Hasil penelitian menunjukkan bahwa persepsi masyarakat nelayan dan persepsi lembaga (stake holder) terkait terhadap pengelolaan suaka perikanan melalui pola ko-manajemen berbeda terhadap pola pengelolaan yang didominasi pemerintah. Kelembagaan terkait dalam pengelolaan suaka perikanan melalui pola ko-manajemen lebih tinggi efektifitasnya dibandingkan dengan pola pengelolaan yang didominasi pemerintah termasuk koordinasi perencanaan pengelolaan suaka perikanan dan partisipasi aktif masyarakat nelayan. Disamping penerapan konsep ko-manajemen dalam pelaksanaan pengelolaan suaka perikanan di perairan umum, gambaran secara kuantitatif kedua pola pengelolaan tersebut baik kondisi biologi, ekologi, persepsi dan keadaan lainnya dikemukakan dalam laporan ini.
\end{abstract}

\section{ABSTRACT: The Application of Co-Management in on Open Waters Fishery Reserve Area. By: Zahri Nasution, Emmy Dharyati, Samuel, Ondara and Agus Djoko Utomo}

A study aimed at comparing co-management applied in an openwaters reserve area in Jambi Province and state management applied in South Sumatra reserve area has been carried out. Data were collected through structure interviews using questionnaires. Descriptive method was used to analyse the data. The results of the research showed that a good perception of fishermen community existed at co-management reserve area and were not present in the state management compared. The community led institution associated with the co-management was found to be more effective in leading to better management results than the state-run management. Co management application resulted in good biology and ecology conditions of the reserve area. Quantitative comparisons between the management are discussed in this paper.

KEYWORDS: co-management, open waters, reserve area, Jambi, South Sumatera, Institution

\section{PENDAHULUAN}

Sumberdaya perikanan di perairan umum Indonesia berperanan dalam penyediaan protein hewani baik bagi masyarakat di pedesaan maupun di perkotaan. Kemudian, banyak pemanfaat yang berkepentingan untuk menggunakan perairan umum dalam proses kehidupannya termasuk kehidupan ikan yang merupakan salah satu sumberdaya alam Indonesia.

Dengan demikian, dalam pengelolaan perairan seperti sungai dan rawa banjiran dalam pembangunan perikanan seharusnya mengikuti pertimbangan antara lain optimasi pemanfaatan sumberdaya dan keseimbangan manfaat antar pengguna (Mellquist, 1992). Hal ini misainya dapat berupa kebijakan mempertahankan upaya penangkapan pada suatu tingkat tertentu yang berhubungan dengan tujuan tertentu (Troadec, 1992).

Pengelolaan sumberdaya perikanan perairan umum di Indonesia sangat beragam dari satu wilayah ke wilayah lainnya baik antar propinsi maupun kabupaten, meskipun telah ada pengaturan yang sifatnya Nasional seperti Undang-Undang Republik Indonesia No. 9 Tahun 1985, ataupun berupa Peraturan

\footnotetext{
\% Peneliti pada Pusat Riset Pengolahan Produk dan Sosial Ekonomi Kelautan dan Perikanan.

*) Peneliti pada Balai Riset Perikanan Perairan Umum, Pusat Riset Perikanan Tangkap.
} 
Pemerintah dan Surat Keputusan baik Menteri maupun Direktur Jenderal di Departemen. Peraturan nasional tersebut dapat berupa campur tangan pemerintah dalam pengaturan seperti zonasi penggunaan tanah, reboisasi, pengaturan suaka perikanan dan lain-lain (Hartwick and Olewiler, 1986). Tetapi perbedaan pengaturan tersebut tercermin dari adanya Peraturan Daerah masing-masing dan adat istiadat yang diberlakukan misalnya pada tingkat desa ataupun kecamatan.

Pendekatan pengelolaan yang berakar pada masyarakat lebih banyak diarahkan langsung terhadap masalah-masalah yang berhubungan pengelolaan dan pembangunan perikanan yang tetap dilaksanakan dibawah program pembangunan perikanan nasional (Pomeroy, 1991), yang didalamnya termasuk unsur-unsur ilmu ekonomi, antropologi, hukum dan politik (Pomeroy, 1993), disamping kriteria limnologis seperti yang dikemukakan oleh Hartoto (2000). Kemudian, karakteristik sosial dan kultural penting pula dipelajari dalam pembangunan perikanan terutama yang berskala kecil (Pollnac, 1988).

Konsep ko-manajemen (pengelolaan bersama) memberikan pengertian sebagai suatu pengaturan kemitraan dengan menggunakan kemampuan dan minat nelayan lokal dan masyarakatnya, yang dilengkapi oleh kemampuan pemerintah untuk menyediakan perangkat hukum yang memungkinkan dan bantuan lainnya yang dapat diterapkan dalam pengelolaan suaka perikanan (Anonymous, 2000). Pelaku perikanan kunci dalam pengelolaan bersama adalah mereka yang terlibat langsung dengan penggunaan sumber daya yaitu nelayan dan anggota keluarganya.

Di lain pihak, pengelolaan suaka perikanan di Indonesia saat ini masih terdapat berbagai pola antara lain yang dikelola secara dominan oleh pemerintah seperti di Sumatera Selatan dan yang dominan dikelola oleh masyarakat seperti yang terdapat di Kalimantan Barat. Pola pengelolaan ini masing-masing mempunyai kelebihan-kelebihan dan kekurangan-kekurangan. Dalam hal ini, berdasarkan hasil penelitian Hoggarth et al., (1999) dapat disimpulkan bahwa penggabungan kedua pola pengelolaan tersebut (ko-manajemen) diharapkan merupakan hasil maksimum yang didapatkan oleh masyarakat tanpa mengabaikan kelestarian sumberdaya perikanan dan peranan pemerintah. Sejauh mana penerapan konsep ko-manajemen dalam pengelolaan suaka perikanan perlu dilakukan penelitian sebagai dasar untuk perbaikan konsep tersebut pada masa yang akan datang. Penelitian ini bertujuan mengetahui dan menganalisis penerapan konsep komanajemen dalam pengelolaan suaka perikanan perairan umum.

\section{METODE}

\section{Lokasi dan Pendekatan Penelitian}

Penelitian ini dilakukan pada lokasi perairan umum yang dikelola melalui penerapan suaka perikanan yang berbeda pola pengelolaannya. Pertama, perairan umum yang dikelola melalui penerapan suaka perikanan yang pengelolaannya mengikuti pola ko-manajemen yaitu perairan Danau Arang-Arang di Kabupaten Batang Hari, Propinsi Jambi. Kedua, perairan umum yang dikelola melalui penerapan suaka perikanan yang pengelolaannya dominan dilakukan pemerintah yaitu perairan Teluk Rasau di Kabupaten Ogan Komering Ilir, Sumatera Selatan.

\section{Penetapan Kelembagaan dan Pemilihan Responden}

Kelembagaan yang ditetapkan sebagai pemanfaat sumberdaya perikanan (stake holder) baik dalam penyusunan rencana pengelolaan suaka perikanan dan penerapan konsep ko-manajemen dalam pengelolaan suaka perikanan di perairan umum adalah Dinas Perikanan Propinsi, Dinas Perikanan Kabupaten, Kepala Desa, Lembaga Ketahanan Masyarakat Desa (LKMD), Lembaga Musyawarah Desa (LMD), Kelompok Tani Nelayan dan lembaga masyarakat atau lembaga lainnya yang terkait.

Nelayan yang ditetapkan sebagai responden adalah masyarakat nelayan yang berada di perairan sekitar suaka perikanan. Untuk Danau Arang-Arang, keseluruhan masyarakat nelayan ditetapkan sebagai populasi dan untuk keperluan responden dalam penelitian ini diambil secara acak (random) sejumlah 38 nelayan. Sedangkan untuk suaka perikanan Teluk Rasau, seluruh nelayan pada perairan sekitarnya (perairan Sungai Aur dan perairan Laut Sekampung di Sungai Lempuing) ditetapkan sebagai nelayan responden sebanyak 22 orang. 


\section{Metode Pengumpulan dan Analisis Data}

Data primer tentang persepsi masyarakat nelayan, efektifitas kelembagaan termasuk koordinasi antar pemanfaat sumberdaya perikanan (stakeholder) dalam penyusunan rencana pengelolaan suaka perikanan dan penerapan konsep ko-manajemen dalam pengelolaan suaka perikanan di perairan umum dikumpulkan melalui wawancara dengan nelayan yang ditetapkan sebagai responden dalam penelitian ini. Kuesioner yang berisikan tentang pertanyaan dan topiktopik yang berhubungan dengan parameter yang diukur disiapkan untuk menjadi panduan dalam mengumpulkan data di lapangan.

Data biologi perikanan berupa data ukuran ikan diperoleh dengan pengukuran langsung dilapangan terhadap ikan contoh yang diperoleh dari hasil tangkapan nelayan. Sedangkan produktivitas hasil tangkapan nelayan didapatkan dari hasil wawancara semi struktural terhadap masyarakat nelayan responden. Data kondisi ekologis perairan diamati langsung diapangan baik melalui wawancara dengan nelayan.

Metode analisis data yang digunakan dalam penelitian ini adalah metode deskriftif dan diinterpretasikan menggunakan metode logik. Metode logik adalah cara menalar dimana data diamati dan dipilah-pilah, buktinya dicari dan dipertimbangkan/ dianalisis dan kemudian kesimpulan diambil (Nazir, 1988).

\section{Data Yang Dikumpulkan dan Konsepsi Pengukurannya}

Persepsi masyarakat nelayan dan persepsi lembaga terkait terhadap pengelolaan suaka perikanan melalui pola ko-manajemen dan pola pengelolaan yang didominasi pemerintah maka parameter yang diukur adalah pendapat masyarakat dan lembaga tersebut terhadap kedua pola pengelolaan tersebut yang ditanyakan langsung terhadap masing-masing nelayan dan terkait. Pendapat tersebut merupakan persepsi yang mencerminkan cara mereka melihat, kekaguman, kepuasan dan lebih dari itu adalah harapan-harapan yang diinginkan, termasuk kesadaran dan pemahaman terhadap hal-hal tertentu (Edmunds and Letey, 1973) serta fenomena lingkungan eksternal (tidak hanya melihat kenyataan obyektif tetapi dilihat pula kenyataan subyektif) (Ditwiler, 1973).
Efektifitas elembagaan terkait dalam pengelolaan suaka perikanan melalui pola komanajemen dan pola pengelolaan yang didominasi pemerintah termasuk koordinasi antar pemanfaat sumberdaya perikanan (stakeholder) dalam penyusunan rencana pengelolaan suaka perikanan dan partisipasi aktif masayarakat nelayan dan unsur pembina dan atau pemanfaat sumberdaya perikanan lainnya dalam penyusunan rencana pengelolaan suaka perikanan. Koordinasi perencanaan pengelolaan suaka perikanan antara lembaga terkait dan atau pemanfaat sumberdaya perikanan tersebut, termasuk didalamnya adalah partisipasi aktif masyarakat nelayan.

Untuk mendapatkan data tentang penerapan konsep ko-manajemen dalam pelaksanaan pengelolaan suaka perikanan di perairan umum dilakukan pengukuran beberapa faktor seperti yang dikemukakan oleh Dahuri et al (1998), yaitu 1). Kesadaran dan tanggung jawab masyarakat dalam menjaga dan memelihara suaka perikanan; 2). Motivasi masyarakat dalam tahapan dan proses pengelolaan suaka perikanan; 3). Bentuk dan variasi pemanfaatan sumberdaya perikanan yang lestari oleh masyarakat nelayan; 4). Pengakuan terhadap hak hukum tradisional atau masyarakat lokal dalam pelaksanaan pengelolaan suaka perikanan; 5). Tingkat pendapatan masyarakat nelayan. Dalam pengukuran berbagai aspek sosial seperti persepsi, partisipasi aktif masyarakat nelayan dan peranan unsur pembina serta berbagai parameter yang digunakan dalam mengukur penerapan ko-manajemen dan data lainnya yang merupakan data kualitatif, dikuantitatifkan menggunakan teknik Thrustone yang mengembangkan penyesuaian khusus dari metode psikologi (Goode dan Hatt, 1986) dengan cara memberikan interval yang konsisten (interval consistency) terhadap jawaban pertanyaan (Eckhardt and Ermann, 1977).

Untuk mengetahui kondisi biologi perikanan baik pada perairan yang dikelola dengan suaka perikanan melalui pola komanajemen maupun pola yang didominasi oleh pemerintah maka parameter yang diamati adalah ukuran ikan dan produktivitas hasil tangkapan nelayan. Kondisi ekologis perairan yang diamati adalah keadaan yang mendukung siklus kehidupan ikan yaitu ketersediaan daerah pemijahan, asuhan, daerah bergerak bebas, dan daerah perlindungan 


\section{HASIL DAN PEMBAHASAN}

\section{Persepsi Masyarakat Nelayan}

Persepsi masyarakat nelayan terhadap pengelolaan suaka perikanan yang dikelola melalui pola ko-manajemen dan pola pengelolaan yang didominasi pemerintah terdiri atas pendapat mereka tentang keberadaan kelompok kerja pengelolaan suaka perikanan, pertemuan dalam rangka pengelolaan suaka perikanan, fungsi kelembagaan terkait dan partisipasi aktif masyarakat nelayan dalam pengelolaan suaka perikanan.

Keberadaan kelompok kerja baik yang terdiri atas anggota masyarakat saja atau gabungan antara masyarakat dan pemerintah yang bekerja mempersiapkan penyusunan rencana pengelolaan sumberdaya perikanan menggambarkan adanya kerjasama antar pemanfaat sumberdaya perikanan di wilayah perairan umum yang dikelola. Kelompok kerja yang merupakan gabungan antara anggota masyarakat dan unsur-unsur pemerintah yang terkait hanya terdapat pada pengelolaan suaka perikanan yang menerapkan pola komanajemen. Di Danau Arang-Arang, kelompok kerja ini merupakan bentuk lembaga yaitu Lembaga Musyawarah Desa (LMD). LMD ini tersusun atas berbagai perwakilan anggota masyarakat yaitu para ketua Rukun Warga, para ketua Rukun Tetangga, para Kepala Dusun, unsur Kepemudaan, LKMD dan tokoh masyarakat lainnya termasuk Kamra dan Ketua Danau (Ketua Kelompok Nelayan).

Berfungsi atau tidaknya kelompok kerja dalam rangka penyusunan rencana pengelolaan suaka perikanan tergambar dari frekuensi pertemuan yang mereka adakan beserta topik yang dibicarakan dalam pertemuan tersebut. Untuk penerapan komanajemen yang dilakukan di Desa ArangArang, pertemuan yang diadakan oleh kelompok kerja penyusunan rencana pengelolaan sumberdaya perikanan minimal 2 (dua) kali dalam setahun yang biasanya dilaksanakan di rumah Kepala Desa. Adapun topik pertemuan yang tetap adalah menentukan besarnya pembayaran sewa perairan baik bagi masyarakat desa setempat maupun masyarakat luar desa Arang-Arang serta penetapan "Hari Berkarang" yang pertama pada saat air menjelang surut.
Topik-topik lainnya tergantung dengan adanya usul dari masyarakat nelayan atau pengaturan lapangan lainnya yang diperlukan, termasuk didalamnya penetapan Ketua Danau yang ditetapkan 2 (dua) tahun sekali. Di lain pihak pada perairan umum yang dikelola dengan pola yang didominasi oleh pemerintah pertemuan seperti ini dilaksanakan oleh unsur pemerintah saja, tidak mengikut sertakan unsur dari nelayan. Dengan demikian aspirasi nelayan tidak dapat tertampung.

Kemudian, berfungsi atau kurang berfungsinya kelembagaan terkait dengan pengelolaan sumberdaya perikanan termasuk pengelolaan suaka perikanan sesuai dengan tugas dan fungsinya masing-masing tergambar dari pendapat masyarakat nelayan. Tugas dan fungsi tersebut misalnya bagi Dinas Perikanan Propinsi Jambi dan Dinas Perikanan Kabupaten Batang Hari telah melakukan penunjukan terhadap petugas jaga suaka perikanan yang disesuaikan dengan hasil musyawarah yang dilakukan oleh lembaga yang ada pada tingkat masyarakat (LMD). Begitu pula Kepala Desa sebagai kelembagaan tingkat desa telah turut pula mengesahkan apa yang menjadi hasil musyawarah LMD guna pengelolaan sumber daya perikanan (termasuk pengelolaan suaka perikanan).

Pengaturan pengelolaan sumberdaya perikanan yang disahkan oleh Kepala Desa setelah diadakan musyawarah LMD dan dibuat dalam bentuk tertulis antara lain adalah penetapan "Hari Berkarang" dan larangan penangkapan ikan secara perorangan menggunakan alat tangkap jaring dan jala sebelum ditetapkannya "Hari Berkarang". Tindakan pengamanan suaka perikanan dengan menerapkan pola ko-manajemen di Danau Arang-Arang, Jambi dapat mengikut sertakan masyarakat nelayan setempat yaitu sekitar 15 orang sebagai anggota masyarakat yang membantu petugas jaga suaka perikanan tersebut di lapangan. Akibat lebih lanjut adalah menuju kepada bertambah efektifnya fungsi suaka perikanan secara keseluruhan terhadap sumberdaya perikanan pada perairan yang dikelola dengan pola komanajemen. Berbeda halnya pada pengelolaan suaka perikanan dengan pola komanajemen, keberadaan dan partisipasi aktif masyarakat nelayan dalam penyusunan rencana pengelolaan suaka perikanan baik yang disampaikan secara lisan ataupun tertulis sangat diperhatikan. 
Perbandingan pentingnya keberadaan kelompok kerja penyusunan rencana pengelolaan sumberdaya perikanan, pertemuan kelompok kerja yang membicarakan pengelolaan suaka perikanan, fungsi kelembagaan terkait dalam pengelolaan sumber daya perikanan, partisipasi aktif masyarakat nelayan dalam penyusunan rencana pengelolaan suaka perikanan diperlihatkan pada Tabel 1.
Pentingnya kelompok kerja penyusunan rencana pengelolaan sumberdaya perikanan ini atas dasar bahwa masyarakat nelayan setempat dapat menyampaikan aspirasinya baik secara lisan maupun secara tertulis kepada pemerintah setempat melalui kelompok kerja tersebut (LMD). Sebagai contoh, misalnya, masyarakat nelayan di Desa Arang-Arang menganggap penting pengendalian gulma yang berada dan

Tabel 1. Frekuensi pendapat masyarakat responden tentang beberapa atribut yang berhubungan dengan penyusunan rencana pengelolaan perikanan perairan umum.

Table 1. Frequency of respondent's opinion regarding attributes related to planning of open-water fishery management

\begin{tabular}{|c|c|c|c|c|c|c|c|c|c|}
\hline & \multirow{2}{*}{$\begin{array}{l}\text { Atribut } \\
\text { Attribute }\end{array}$} & \multicolumn{4}{|c|}{$\begin{array}{l}\text { Ko-Manajemen } \\
\text { Co-management }\end{array}$} & \multicolumn{4}{|c|}{$\begin{array}{l}\text { Dominasi Pemerintah } \\
\text { State-run management }\end{array}$} \\
\hline & & 1 & 2 & 3 & 4 & 1 & 2 & 3 & 4 \\
\hline 1 & $\begin{array}{l}\text { Keberadaan Kelompok } \\
\text { Kerja Penyusunan Rencana } \\
\text { Pengelolaan Suaka } \\
\text { Perikanan/ Existency of } \\
\text { Working Group on the } \\
\text { Fishery Reserve } \\
\text { Management Plan }\end{array}$ & $\begin{array}{c}0 \\
(0)\end{array}$ & $\begin{array}{c}0 \\
(0)\end{array}$ & $\begin{array}{c}10 \\
(26)\end{array}$ & $\begin{array}{l}28 \\
(74)\end{array}$ & $\begin{array}{c}17 \\
(77)\end{array}$ & $\begin{array}{c}5 \\
(23)\end{array}$ & $\begin{array}{c}0 \\
(0)\end{array}$ & $\begin{array}{c}0 \\
(0)\end{array}$ \\
\hline 2 & $\begin{array}{l}\text { Pertemuan Pengelolaan } \\
\text { Suaka Perikanan/ Fishery } \\
\text { Reserve Management } \\
\text { Meeting }\end{array}$ & $\begin{array}{c}0 \\
(0)\end{array}$ & $\begin{array}{c}0 \\
(0)\end{array}$ & $\begin{array}{c}8 \\
(21)\end{array}$ & $\begin{array}{c}30 \\
(79)\end{array}$ & $\begin{array}{c}16 \\
(73)\end{array}$ & $\begin{array}{c}6 \\
(27)\end{array}$ & $\begin{array}{c}0 \\
(0)\end{array}$ & $\begin{array}{c}0 \\
(0)\end{array}$ \\
\hline 3 & $\begin{array}{l}\text { Fungsi Kelembagaan terkait } \\
\text { dalam Pengelolaan Suaka } \\
\text { Perikanan/ Funtion of } \\
\text { Related Institutions }\end{array}$ & $\begin{array}{c}0 \\
(0)\end{array}$ & $\begin{array}{c}0 \\
(0)\end{array}$ & $\begin{array}{c}13 \\
(34)\end{array}$ & $\begin{array}{c}25 \\
(66)\end{array}$ & $\begin{array}{c}12 \\
(55)\end{array}$ & $\begin{array}{c}10 \\
(45)\end{array}$ & $\begin{array}{c}0 \\
(0)\end{array}$ & $\begin{array}{c}0 \\
(0)\end{array}$ \\
\hline 4 & $\begin{array}{l}\text { Partisipasi Aktif Masyarakat } \\
\text { Nelayan Dalam Penyusunan } \\
\text { Rencana Pengelolaan } \\
\text { Suaka Perikanan/ } \\
\text { Fishermen Society } \\
\text { Participation on the Fishery } \\
\text { Reserve Management Plan }\end{array}$ & $\begin{array}{c}0 \\
(0)\end{array}$ & $\begin{array}{c}0 \\
(0)\end{array}$ & $\begin{array}{c}8 \\
(21)\end{array}$ & $\begin{array}{c}30 \\
(79)\end{array}$ & $\begin{array}{c}18 \\
(82)\end{array}$ & $\begin{array}{c}4 \\
(18)\end{array}$ & $\begin{array}{c}0 \\
(0)\end{array}$ & $\begin{array}{c}0 \\
(0)\end{array}$ \\
\hline
\end{tabular}

Keterangan/Remark: Angka-angka 1, 2, 3 dan 4 merupakan nilai skor mulai yang terendah hingga tertinggi yang mengindikasikan mulai dari sangat buruk, buruk, baik dan sangat baik/Number 1,2,3 and 4 are score indicates the very bad, bad, good and very good condition.

Tabel 1 menggambarkan bahwa pada atribut pertama sebagian besar atau $74 \%$ masyarakat nelayan yang melaksanakan penangkapan ikan pada perairan umum yang menerapkan suaka perikanan dengan pola ko-manajemen menganggap penting keberadaan kelompok kerja pengelolaan sumberdaya perikanan dimana didalamnya termasuk pengelolaan suaka perikanan. Sedangkan pada masyarakat nelayan perairan umum yang menerapkan suaka perikanan yang dikelola dengan pola yang didominasi oleh pemerintah hanya $23 \%$ yang menganggap penting keberadaanya. menutupi sebagian besar perairan Danau Arang-Arang.

Kemudian, dengan adanya kelompok kerja ini maka pembiayaan pengelolaan suaka perikanan dan ataupun sumberdaya perikanan secara menyeluruh di perairan Danau Arang-Arang ini dapat memanfaatkan dana kas masyarakat nelayan yang dikumpulkan dari pembayaran izin penangkapan bagi masyarakat di luar desa ArangArang. Hal ini didukung pula dengan keadaan bahwa petugas jaga suaka perikanan pada perairan umum yang dikelola dengan pola ko- 
manajemen diambil dari salah seorang yang ditokohkan masyarakat, sedangkan pada pengelolaan suaka perikanan yang dikelola dengan dominasi pemerintah tidak mempertimbangkan pengaruh aspek sosial seseorang penjaga suaka perikanan terhadap masyarakat nelayan. Hal ini bersesuaian dengan azas aturan representasi yang dikemukakan oleh Pakpahan (1989) yang merupakan salah satu unsur penyusun kelembagaan yang penting dalam mencapai penerapan suaka perikanan.

Pada atribut kedua diperlihatkan pula bahwa sebagian besar atau $79 \%$ masyarakat nelayan yang melaksanakan penangkapan ikan pada perairan umum yang menerapkan suaka perikanan dengan pola ko-manajemen menyatakan ada pertemuan yang dilakukan oleh kelompok kerja pengelolaan sumberdaya perikanan terutama di Desa Arang-Arang, Jambi. Sedangkan pada masyarakat nelayan perairan umum yang menerapkan suaka perikanan yang dikelola dengan pola yang didominasi oleh pemerintah hanya $27 \%$ yang menyatakan adanya pertemuan, tetapi pertemuan ini tidak mengikutsertakan perwakilan dari masyarakat nelayan.

Kemudian, pada atribut ketiga terlihat bahwa sebagian besar atau $66 \%$ masyarakat nelayan yang melaksanakan penangkapan ikan pada perairan umum yang menerapkan suaka perikanan dengan pola ko-manajemen menyatakan bahwa kelembagaan terkait dalam pengelolaan sumberdaya perikanan telah berfungsi sesuai dengan tugas dan fungsinya masing-masing. Dilain pihak, pada masyarakat nelayan perairan umum yang menerapkan suaka perikanan yang dikelola dengan pola yang didominasi oleh pemerintah hanya $45 \%$ yang menyatakan bahwa kelembagaan terkait berfungsi sesuai dengan tugas dan fungsinya. Sedangkan $55 \%$ masyarakat lainnya menyatakan bahwa kelembagaan terkait belum disesuaikan dengan tugas dan fungsinya. Termasuk didalamnya belum mengikutsertakan anggota masyarakat nelayan atau organisasi nelayan dalam musyawarah pengelolaan sumberdaya perikanan.

Pada atribut yang keempat, terlihat bahwa sebagian besar atau $79 \%$ masyarakat nelayan yang melaksanakan penangkapan ikan pada perairan umum yang menerapkan suaka perikanan dengan pola ko-manajemen menyatakan mereka sangat aktif untuk berpartisipasi dalam pengelolaan sumberdaya perikanan, termasuk pengelolaan suaka perikanan perairan umum. Artinya setiap ada rencana rapat yang dilakukan oleh LMD masyarakat aktif mengusulkan sesuatu untuk kepentingan masyarakat banyak. Hal ini sesuai dengan prinsip kelembagaan dalam ko-manajemen yang menyatakan bahwa setiap aturan permainan dapat saja diubah asalkan telah merupakan suatu kesepakatan bagi pengguna dan pembuat aturan itu sendiri (Pomeroy, 1991). Sebagai contoh misalnya pada tahun 2000 yang lalu sebagian besar warga masyarakat desa Arang-Arang menginginkan agar biaya izin penangkapan yang biasanya dibayar oleh warga sebesar Rp.10.000.- per kepala keluarga tidak dipungut pada tahun tersebut. Pengajuan ini dibawa dan disetujui oleh rapat dan musyawarah LMD kemudian selanjutnya disahkan oleh Kepala Desa.

\section{Efektifitas Kelembagaan Pengelolaan Suaka Perikanan}

Efektifitas kelembagaan terkait dalam pengelolaan suaka perikanan melalui pola komanajemen dan pola pengelolaan yang didominasi pemerintah dalam penyusunan rencana pengelolaan suaka perikanan terlihat dari unsur-unsur batas yurisdiksi, hak dan kewajiban dan aturan representasi. Kelembagaan yang dimaksudkan dalam hal ini adalah Dinas Perikanan Propinsi, Dinas Perikanan Kabupaten, Kepala Desa, Lembaga Ketahanan Masyarakat Desa (LKMD), Lembaga Musyawarah Desa (LMD) dan kelembagaan desa lainnya seperti Kelompok Nelayan dan Kelompok Pemuda.

Sebagai contoh misalnya pada perairan umum yang dikelola dengan penerapan suaka perikanan pola ko-manajemen, Dinas Perikanan Propinsi Jambi dan Dinas Perikanan Kabupaten Batanghari telah menetapkan kebijakan pengelolaan suaka perikanan dan petugas jaga suaka perikanan. Masing-masing pengaturan tersebut dalam bentuk Surat Keputusan Kepala Dinas Perikanan Propinsi Jambi untuk penetapan petugas jaga suaka perikanan dan Bupati Kabupaten Batanghari untuk penetapan Danau Arang-Arang sebagai suaka perikanan.

Dilain pihak, LMD dengan musyawarahnya menetapkan pengaturan tentang penangkapan ikan di perairan Danau Arang-Arang yang selanjutnya disahkan oleh Kepala Desa. 
Pengaturan tersebut antara lain adalah izin penangkapan ikan baik untuk masyarakat desa Arang-Arang maupun luar desa.

Penetapan sewa bagi masyarakat luar desa untuk melakukan penangkapan ikan di Danau Arang-Arang merupakan cara yang ditempuh untuk membatasi nelayan luar desa untuk beroperasi di Danau Arang-Arang. Hal ini sesuai dengan prinsip bahwa dalam komanajemen terjadi pembagian tanggungjawab dan wewenang antara pemerintah dan masyarakat lokal dalam pengelolaan sumberdaya alam (Pomeroy and Williams, 1994).

Disamping itu, peraturan mengenai penegakan hukum terhadap pelanggaran yang dilakukan oleh masyarakat luar desa ditetapkan tanpa melalui peringatan terlebih dahulu yang dibedakan terhadap masyarakat desa yang terlebih dahulu mendapatkan peringatan. Dalam hal ini tidak ada intervensi Dinas Perikanan atau Kepolisian atau pihak pemerintah lainnya dalam rangka penetapan sanksi bagi pelanggaran terhadap aturan yang ada. Secara kuantitatif pendapat nelayan tentang dua atribut yang berhubungan dengan kelembagaan terkait dalam pengelolaan perikanan perairan umum dicantumkan pada Tabel 2 .
Tabel 2 menunjukkan bahwa pada atribut yang pertama, sebagian besar atau $84 \%$ masyarakat nelayan yang melaksanakan penangkapan ikan pada perairan umum yang menerapkan suaka perikanan dengan pola ko-manajemen menyatakan bahwa kelembagaan yang terkait dalam pengelolaan sumberdaya perikanan, termasuk pengelolaan suaka perikanan perairan umum sangat efektif. Artinya setiap kelembagaan yang terkait tersebut bertugas dan berfungsi sesuai dengan tugas dan fungsi mereka masingmasing. Dalam hal ini masyarakat nelayan menganggap bahwa meskipun perairan umum yang ada di desa mereka tetapi menurut mereka masih diperlukan campur tangan pemerintah.

Campur tangan pemerintah yang diperlukan masyarakat nelayan antara lain adalah pengendalian tumbuhan yang menutupi perairan baik yang terdapat pada perairan umum maupun suaka perikanan. Disamping itu, misalnya nelayan mencontohkan dalam hal penebaran ikan kembali ke perairan umum dalam rangka penambahan populasi ikan di perairan umum. Hal ini sejalan dengan pernyataan bahwa pemerintah perlu campur tangan terutama terhadap pengelolaan sumberdaya perikanan yang sifatnya milik bersama (Crutchfield, 1987).

Tabel 2. Frekuensi pendapat masyarakat responden tentang beberapa atribut yang berhubungan dengan kelembagaan terkait dalam pengelolaan perikanan perairan umum.

Table 2. Frequency of respondent's opinion regarding attributes related to institutions associated with open-water fishery management

\begin{tabular}{|c|c|c|c|c|c|c|c|c|c|}
\hline & \multirow{2}{*}{$\begin{array}{l}\text { Atribut } \\
\text { Attribute }\end{array}$} & \multicolumn{4}{|c|}{$\begin{array}{l}\text { Ko-Manajemen } \\
\text { Co-management }\end{array}$} & \multicolumn{4}{|c|}{$\begin{array}{l}\text { Dominasi Pemerintah } \\
\text { State-run management }\end{array}$} \\
\hline & & 1 & 2 & 3 & 4 & 1 & 2 & 3 & 4 \\
\hline 1 & $\begin{array}{l}\text { Efektifitas Kelembagaan yang } \\
\text { terkait dalam Pengelolaan } \\
\text { Sumberdaya Perikanan } \\
\text { Perairan Umum } \\
\text { IEffectiveness of Institution in } \\
\text { Open Water Fishery } \\
\text { management }\end{array}$ & $\begin{array}{c}0 \\
(0)\end{array}$ & $\begin{array}{c}0 \\
(0)\end{array}$ & $\begin{array}{c}6 \\
(16)\end{array}$ & $\begin{array}{c}32 \\
(84)\end{array}$ & $\begin{array}{c}7 \\
(32)\end{array}$ & $\begin{array}{c}15 \\
(68)\end{array}$ & $\begin{array}{c}0 \\
(0)\end{array}$ & $\begin{array}{c}0 \\
(0)\end{array}$ \\
\hline 2 & $\begin{array}{l}\text { Koordinasi Perencanaan } \\
\text { Pengelolaan Suaka Perikanan } \\
\text { termasuk Partisipasi } \\
\text { Masyarakat Nelayan/Planning } \\
\text { Coordination and People } \\
\text { Participation in the } \\
\text { Establishment of the Fishery } \\
\text { Reserve }\end{array}$ & $\begin{array}{c}0 \\
(0)\end{array}$ & $\begin{array}{c}0 \\
(0)\end{array}$ & $\begin{array}{c}18 \\
(47)\end{array}$ & $\begin{array}{c}20 \\
(53)\end{array}$ & $\begin{array}{c}15 \\
(68)\end{array}$ & $\begin{array}{c}7 \\
(32)\end{array}$ & $\begin{array}{c}0 \\
(0)\end{array}$ & $\begin{array}{c}0 \\
(0)\end{array}$ \\
\hline & $\begin{array}{l}\text { angan/Remark: Angka-angka } \\
\text { hingga tertinggi yang mer } \\
\text { baik/Number } 1,2,3 \text { and } 4 \\
\text { condition. }\end{array}$ & & & 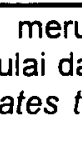 & 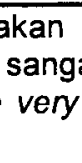 & $\mathrm{s}$ & . & & $\begin{array}{l}\text { dah } \\
\text { ogat } \\
\text { ood }\end{array}$ \\
\hline
\end{tabular}


Dilain pihak, pada pengelolaan suaka perikanan yang didominasi oleh pemerintah, $68 \%$ masyarakat nelayan berpendapat bahwa kelembagaan yang terkait dalam pengelolaan sumberdaya perikanan perairan umum kurang efektif. Sedangkan 32\% masyarakat nelayan menganggap kelembagaan tersebut tidak aktif sama sekali. Dalam hal ini mereka berpendapat bahwa pemerintah hanya memungut hasil sewa perairan saja sedangkan konservasi sumberdaya perikanan sangat kurang diperhatikan.

Disamping itu, koordinasi perencanaan pengelolaan suaka perikanan antara lembaga terkait dan atau pemanfaat sumberdaya perikanan tersebut, termasuk pula didalamnya adalah partisipasi aktif masyarakat nelayan baik berupa usul kepada Ketua Danau atau Ketua Kelompok Nelayan (atribut kedua) menunjukkan bahwa sebagian besar atau $53 \%$ masyarakat nelayan yang melaksanakan penangkapan ikan pada perairan umum yang menerapkan suaka perikanan dengan pola ko-manajemen menyatakan bahwa koordinasi perencanaan pengelolaan suaka perikanan telah berjalan sangat baik termasuk partisipasi masyarakat nelayan dalam perencanaan tersebut. Hal ini memberikan pengertian bahwa pengelolaan sumberdaya perikanan, termasuk pengelolaan suaka perikanan pada pola ko-manajemen cukup terencana dan masyarakat turut serta dalam perencanaan tersebut.

Berbeda halnya pada pengelolaan suaka perikanan yang didominasi oleh pemerintah, $68 \%$ masyarakat nelayan berpendapat bahwa tidak mengetahui apakah pernah terjadi koordinasi dalam perencanaan pengelolaan suaka perikanan tetapi masyarakat nelayan tidak pernah berpartisipasi dalam perencanaan tersebut. Dalam hal ini mereka berpendapat bahwa mengelola suaka perikanan merupakan tugas dan kewajiban pemerintah.

\section{Penerapan Konsep Ko-manajemen}

Penerapan konsep ko-manajemen dalam pelaksanaan pengelolaan suaka perikanan di perairan umum terdiri atas beberapa variabel yaitu kesadaran dan tanggung jawab masyarakat dalam menjaga dan memelihara suaka perikanan, motivasi masyarakat dalam tahapan dan proses pengelolaan suaka perikanan, bentuk dan variasi pemanfaatan sumberdaya perikanan yang lestari oleh masyarakat nelayan, pengakuan terhadap hak hukum tradisional atau masyarakat lokal dalam pelaksanaan pengelolaan suaka perikanan, dan tingkat pendapatan masyarakat nelayan.

Tanggung jawab masyarakat nelayan dalam menjaga dan memelihara suaka perikanan yang ada dicatat dalam bentuk aplikasinya antara lain tidak menggunakan racun atau tuba atau listrik dalam melaksanakan penangkapan ikan. Disamping itu juga turut menjaga kegiatan yang dilaksanakan nelayan lainnya di perairan pada waktu yang bersamaan dengan pelaksanaan penangkapan ikan. Hal demikian secara kuantitatif dicantumkan pada Tabel 3

Tabel 3 pada atribut pertama menunjukkan bahwa sebagian besar atau $82 \%$ masyarakat nelayan yang melaksanakan penangkapan ikan pada perairan umum yang menerapkan suaka perikanan dengan pola ko-manajemen menyatakan bahwa mereka sangat menyadari dan merasa sangat bertanggung jawab dalam menjaga dan memelihara suaka perikanan yang ada di desa atau perairan tempat mereka melaksanakan penangkapan ikan. Hal ini memberikan pengertian bahwa pengelolaan sumberdaya perikanan, penjagaan dan pemeliharaan serta pengelolaan suaka perikanan pada pola ko-manajemen tidak hanya dilakukan oleh satu orang saja seperti yang terdapat dalam surat keputusan Kepala Dinas di Jambi.

Kesadaran dan tanggungjawab masyarakat nelayan tersebut tercermin dari hasil survey yang menunjukkan bahwa pada desa ArangArang terdapat minimal 4 (empat) anggota masyarakat nelayan yang dipercaya Ketua Danau untuk mengawasi penangkapan ikan. Jika ada kejadian tentang pencurian ikan di suaka perikanan atau seseorang mencuri ikan milik nelayan lainnya maka orang yang dipercaya tersebut melapor kepada Ketua Danau untuk selanjutnya ditindaklanjuti. Hal ini sesuai dengan hasil wawancara dengan Kepala Desa dan Ketua Danau serta Ketua Keamanan Rakyat (KAMRA) yang dapat disimpulkan bahwa sistem pengawasan suaka perikanan yang diterapkan di desa ArangArang adalah sistem pengawasan yang dilaksanakan oleh masyarakat secara bersama. Kemudian dalam pelaksanaannya di lapangan dibantu oleh 15 orang yang dipercaya oleh Ketua Keamanan dan Ketua Danau berfungsi sebagai pengawas lapangan 
yang utama untuk pengamanan suaka perikanan. Berbeda halnya pada pengelolaan suaka perikanan yang didominasi oleh pemerintah, untuk atribut pertama, sebagian besar atau $73 \%$ masyarakat nelayan terihat tidak menyadari dan tidak merasa bertanggung jawab terhadap penjagaan dan pemeliharaan suaka perikanan. Seperti dikemukakan diatas bahwa dalam hal ini mereka berpendapat bahwa mengelola suaka perikanan merupakan tugas dan kewajiban pemerintah.

Motivasi masyarakat nelayan dalam tahapan pengelolaan suaka perikanan dan faktor pendorong nelayan untuk turut serta dalam menjaga dan memelihara suaka perikanan yang ada di wilayah perairan umum antara lain nelayan menyatakan bahwa agar mereka mendapatkan ikan yang berukuran besar sehingga harganya mahal dan usulan lainnya antara lain supaya tidak menangkap benih ikan seperti gabus dan toman, dengan nilai yang dikuantifikasi seperti yang terlihat pada Tabel 3 atribut yang kedua yang menunjukkan bahwa sebagian besar atau $74 \%$ masyarakat nelayan yang melaksanakan penangkapan ikan pada perairan umum yang perikanan. Sebagai contoh misalnya masyarakat nelayan menginginkan agar ikanikan yang mereka tangkapi berukuran besarbesar sehingga jika dijual harganya mahal.

Disamping itu masyarakat nelayan di wilayah ini tidak pernah melaksanakan hal-hal yang dilarang oleh aturan desa dan pemerintah. Hal ini memberikan pengertian bahwa penjagaan dan pemeliharaan serta pengelolaan suaka perikanan pada pola komanajemen juga harus ada suatu motivasi yang menguntungkan secara bersama yaitu agar masyarakat nelayan mempunyai sumber pendapatan sepanjang tahun.

Tabel 3. Frekuensi pendapat masyarakat responden tentang beberapa atribut yang berhubungan dengan kelembagaan terkait dalam pengelolaan perikanan perairan umum.

Table 3. Frequency of respondent's opinion regarding attributes related to institution in open water fishery management

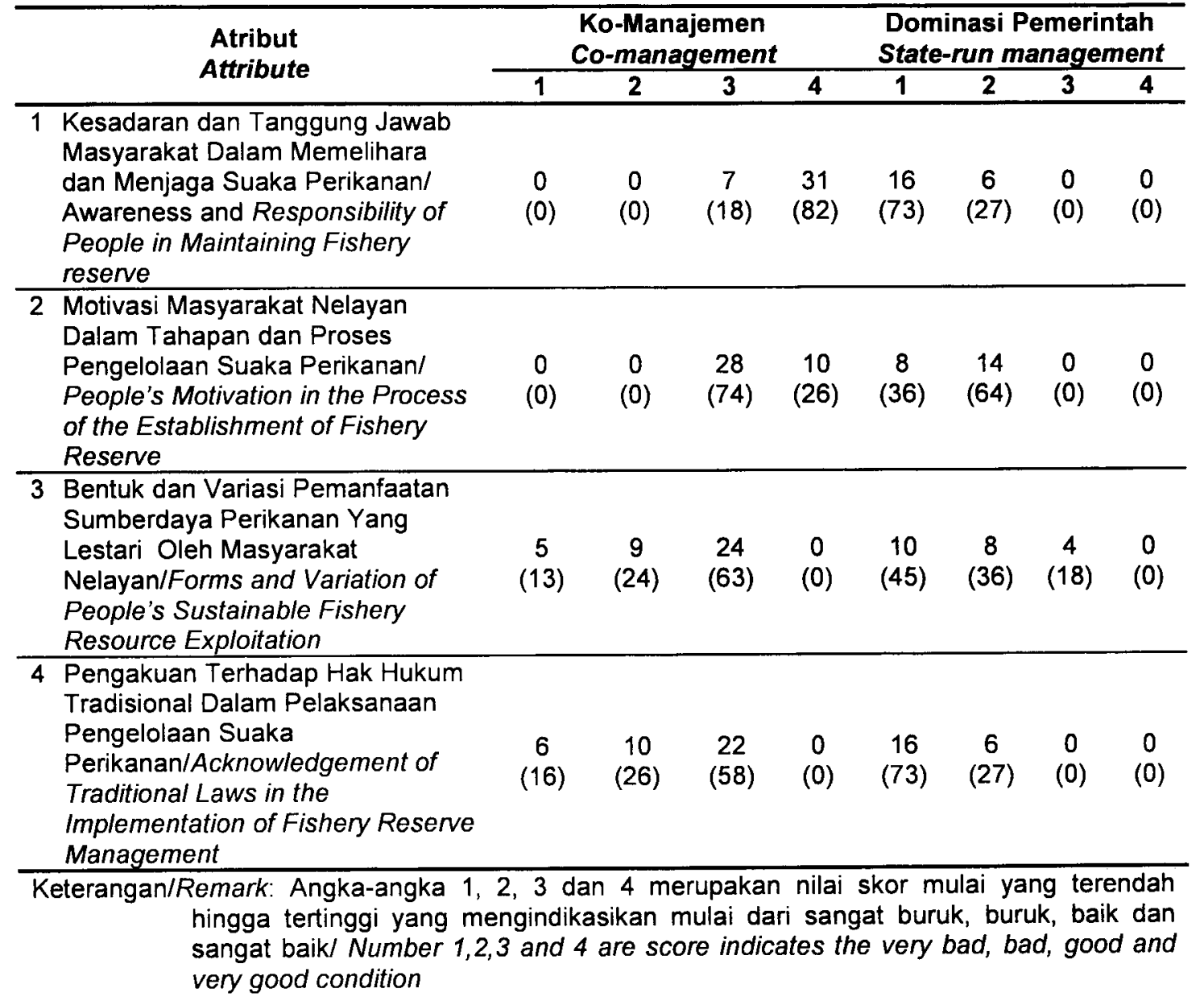


Aplikasi dari motivasi masyarakat nelayan tersebut tercermin dari hasil survey yang menerapkan suaka perikanan dengan pola ko-manajemen memiliki motivasi yang sebenarnya merupakan dorongan untuk turut serta menjaga dan memelihara suaka menunjukkan bahwa pada desa Arang-Arang, anggota masyarakat nelayan sama-sama mengetahui bahwa tidak menangkapi ikanikan yang berukuran kecil guna menjaga populasi ikan agar tumbuh. Disamping itu, masyarakat nelayan juga tidak menebang hutan rawa yang ada di sekitar suaka perikanan. Karena hutan rawa tersebut berguna untuk menyediakan tempat berlindung dan berdiam bagi ikan dan populasinya (Utomo et al., 1997).

Untuk atribut kedua tersebut, berbeda halnya pada pengelolaan suaka perikanan yang didominasi oleh pemerintah, sebagian besar atau $64 \%$ masyarakat nelayan terlihat kurang mempunyai motivasi untuk turut menjaga dan memelihara suaka perikanan. Bahkan 36\% masyarakat tersebut tidak mempunyai motivasi untuk menjaga dan memelihara suaka perikanan. Dalam hal ini mereka tetap berpendapat bahwa mengelola suaka perikanan merupakan tugas dan kewajiban pemerintah.

Bentuk dan variasi pemanfaatan sumberdaya perikanan yang dilaksanakan oleh masyarakat nelayan yang dapat digolongkan kepada kategori pemanfaatan yang lestari antara lain berupa penggunaan alat tangkap dengan mata jaring yang lebih besar dari 1 (satu) inchi seperti tembilar kawat, sedangkan skor nilai secara kuantitatif untuk atribut yang ketiga Tabel 3, menunjukkan bahwa sebagian besar atau $63 \%$ masyarakat nelayan yang melaksanakan penangkapan ikan pada perairan umum yang menerapkan suaka perikanan dengan pola ko-manajemen menerapkan minimal 3 (tiga) macam variasi dan bentuk alat penangkapan ikan yang tetap memperhatikan kelestarian sumber daya perikanan. Alat tersebut antara lain tembilar kawat, bubu apollo dan lukah dimana ketiganya mempunyai mata jaring lebih dari 1 inchi, sedangkan alat tangkap listrik dan tuba sejak dahulu tidak pernah mereka gunakan untuk menangkap ikan. Tetapi terdapat juga 13\% masyarakat tersebut tidak memperhatikan kelestarian sumberdaya perikanan seperti tangkul kerap (small mesh size lift-net) dengan mata jaring $0,5 \mathrm{~cm}$.

Dilain pihak, untuk atribut yang ketiga tetapi pada perairan umum yang pengelolaannya didominasi pemerintah sebagian besar atau sebesar $45 \%$ masyarakat nelayan tidak memperhatikan kelestarian sumberdaya perikanan sama sekali. Hanya $18 \%$ yang mempertimbangkan kelestarian sumbedaya perikanan. Contoh cara penangkapan ikan yang dilaksanakan masyarakat yang tidak memperhatikan kelestarian sumberdaya perikanan antara lain adalah penangkapan anak-anak ikan toman dan gabus menggunakan jala (cast net) pada saat air besar yang sekaligus menangkap induknya. Disamping itu, masyarakat nelayan juga menangkap ikan tambakan yang sedang bertelur di perairan lebak.

Apakah terdapat pengakuan terhadap hakhak hukum tradisional atau pengaturanpengaturan sebelumnya yang berasal dari masyarakat lokal dan saat ini menjadi pengaturan dalam pelaksanaan pengelolaan suaka perikanan ditandai dengan adanya pengaturan yang berlaku sejak lama hingga saat ini. Pengaturan ini diketahui dengan adanya penambahan pengaturan yang dilakukan dalam penyusunan rencana pengelolaan suaka perikanan misalnya dalam Rapat LMD yang skor nilainya dicantumkan pada Tabel 1 atribut yang keempat, yang menunjukkan bahwa sebagian besar atau $58 \%$ masyarakat nelayan yang melaksanakan penangkapan ikan pada perairan umum yang menerapkan suaka perikanan dengan pola ko- manajemen menyatakan bahwa terdapat pengakuan terhadap hak hukum tradisional pada penerapan pola ko-manajemen sekarang ini. Hanya 16\% masyarakat nelayan yang menyatakan tidak terdapat pengakuan terhadap hak hukum tradisional.

Dilain pihak, untuk atribut keempat tetapi pada perairan umum yang pengelolaannya didominasi pemerintah sebagian besar atau sebesar $73 \%$ masyarakat nelayan menyatakan tidak terdapat pengakuan terhadap hak hukum tradisional. Sedangkan 27\% menyatakan ada pengakuan terhadap hak hukum tradisional terutama tentang batasbatas antara perairan yang satu dengan yang lainnya. Selebihnya merupakan pengaturan yang baru yang berubah sejak terjadinya perpindahan sistem pelelangan dari pemerintah Marga ke pemerintahan Kabupaten. 


\section{Kondisi Bio-Ekologi Perairan}

Adapun kondisi biologi perikanan baik pada perairan yang dikelola dengan suaka perikanan melalui pola ko-manajemen maupun pola yang didominasi oleh pemerintah yang digambarkan dengan ukuran individu ikan 5 tahun yang lalu untuk beberapa jenis ikan ekonomis penting adalah semakin mengecil yang diperlihatkan pada tabel 4 .
Tabel 4 memperlihatkan bahwa baik pada perairan umum yang menerapkan suaka perikanan dengan pola ko-manajemen maupun dengan pola pengelolaan yang didominasi oleh pemerintah sama-sama terdapat ukuran individu ikan yang mengecil untuk 7 (tujuh) jenis ikan yang sama. Kemudian produktivitas hasil tangkapan nelayan yang digambarkan dengan keadaan jumlah hasil tangkapan ikan per satuan waktu

Tabel 4. Kondisi ukuran individu ikan di wilayah periran umum yang dikelola dengan penerapan suaka perikanan pola ko-manajemen dan dominasi pemerintah.

Table 4. Individual fish sizes found in the open water areas, managed using fishery reserve management implemented through co-management and state-management

\begin{tabular}{lcc}
\hline $\begin{array}{c}\text { Pola Pengelolaan Suaka } \\
\text { Perikanan dan Jenis Ikan }\end{array}$ & $\begin{array}{c}\text { Rata-Rata Ukuran Individu Ikan (gram/ekor) } \\
\text { Average fish size (gram/ekor) }\end{array}$ \\
\cline { 2 - 3 } Type of management and Fish Species & $\begin{array}{c}\text { Tahun 2001 } \\
\text { Year 2001 }\end{array}$ & $\begin{array}{c}\text { Tahun 1996 } \\
\text { Year 1996 }\end{array}$ \\
\hline Ko-Manajemen (Co-management) & & \\
- Ikan Toman (Channa micropeltes) & $1.000-2.000$ & $4.000-5.000$ \\
- Ikan Gabus (Channa striatus) & $1.000-1.500$ & $2.000-3.000$ \\
- Ikan Bujuk (Channa melnopterus) & $250-500$ & $1.000-1.500$ \\
- Ikan Serandang (Channa pleurophtalmus) & $250-500$ & $1.000-1500$ \\
- Ikan Tambakan (Helostoma temmincki) & $50-100$ & $100-150$ \\
- Ikan Sepat Siam (T. pectoralis) & $50-60$ & $100-125$ \\
- Ikan Keli (Clarias sp) & $200-300$ & $400-500$ \\
Dominasi Pemerintah (State-run management) & & \\
- Ikan Toman (Channa micropeltes) & $1.000-1.500$ & $2.000-3.000$ \\
- Ikan Gabus (Channa striatus) & $600-1.000$ & $1.000-2.000$ \\
- Ikan Bujuk (Channa melnopterus) & $350-500$ & $1.500-2.000$ \\
- Ikan Serandang (Channa pleurophtalmus) & $300-400$ & $500-1.000$ \\
- Ikan Tambakan (Helostoma temmincki) & $50-60$ & $80-100$ \\
- Ikan Sepat Siam (T. pectoralis) & $\mathbf{4 0 - 5 0}$ & $80-100$ \\
- Ikan Keli (Clarias sp) & $100-200$ & $300-400$ \\
\hline
\end{tabular}

Tabet 5. Kondisi produktivitas hasil tangkapan nelayan pada perairan umum yang dikelola dengan suaka perikanan yang dikelola melalui pola ko-manajemen dan dominasi pemerintah.

Table 5. Fishermen catch productivity condition in openwater area, management using fish sanctury management implemented through co-management and state-run management

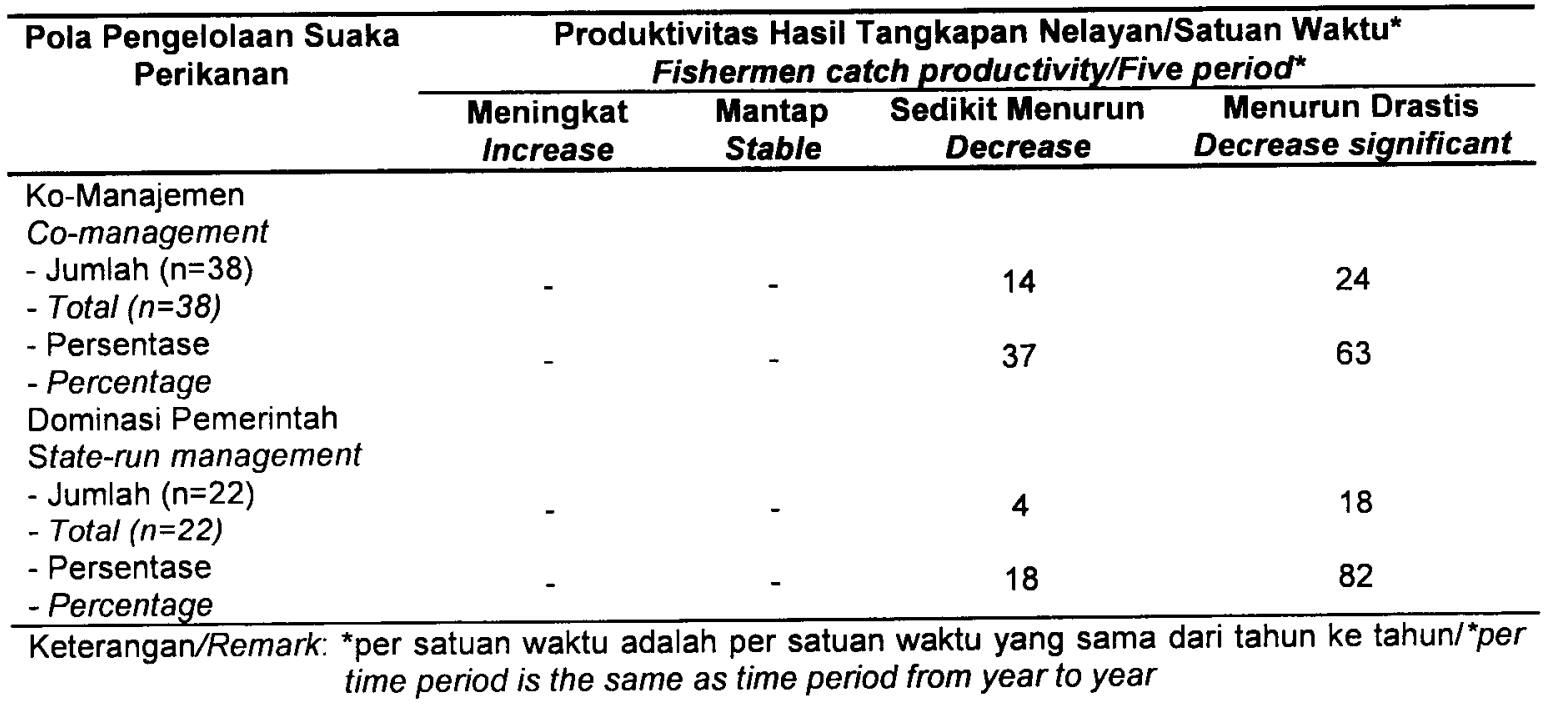


yang sama dari tahun ke tahun juga menurun pada kedua jenis pola pengelolaan suaka perikanan tersebut, yang digambarkan dengan pendapat nelayan seperti yang terlihat pada Tabel 5.

Tabel 5 memperlihatkan bahwa baik pada perairan umum yang menerapkan suaka perikanan dengan pola ko-manajemen maupun dengan pola pengelolaan yang didominasi oleh pemerintah sama-sama terdapat penurunan produktivitas hasil tangkapan nelayan, tetapi kondisi penurunan drastis terdapat pada perairan umum yang pengelolaannya didominasi oleh pemerintah.

Sedangkan kondisi ekologis perairan baik pada perairan yang dikelola melalui penerapan suaka perikanan dengan pola ko-
Tabel 6 memberikan gambaran bahwa keadaan yang memberikan dukungan bagi siklus kehidupan ikan baik untuk spawning ground (daerah pemijahan), nursery ground (daerah untuk pengasuhan), roaming site (daerah untuk bergerak bebas), feeding ground (daerah untuk tempat mencari makan), dan refuge site (daerah untuk tempat berlindung) adalah relatif sama.

\section{KESIMPULAN}

Sebagian besar masyarakat nelayan yang melaksanakan penangkapan ikan pada perairan umum yang menerapkan suaka perikanan dengan pola ko-manajemen lebih mengetahui bahwa pemanfaat sumberdaya perikanan bukan hanya didapatkan oleh

Tabel 6. Distribusi pendapat nelayan tentang perbandingan kondisi dukungan siklus kehidupan ikan pada perairan umum yang dikelola dengan suaka perikanan yang dikelola dengan penerapan pola ko-manajemen dan dominasi pemerintah.

Table 6. Distribution of respondent's opinion regarding the proportion of condition of supports for fish life cycles in open water managed using fish sanctuary, managed through comanagement and state management

\begin{tabular}{|c|c|c|c|}
\hline \multirow{2}{*}{$\begin{array}{l}\text { Pola Pengelolaan } \\
\text { Suaka Perikanan } \\
\text { Type of management }\end{array}$} & \multicolumn{3}{|c|}{$\begin{array}{c}\text { Perbandingan Kondisi Pendukung Siklus } \\
\text { Kehidupan Ikan/Proportion of Condion of Supports } \\
\text { for Fish Life Cycle } \\
\end{array}$} \\
\hline & $\begin{array}{c}\text { Banyak } \\
\text { Big }\end{array}$ & $\begin{array}{c}\text { Sedang } \\
\text { Moderate }\end{array}$ & $\begin{array}{l}\text { Sedikit } \\
\text { Small }\end{array}$ \\
\hline $\begin{array}{l}\text { Ko-Manajemen }(n=38) \text { (Co-management) } \\
\text { - Daerah pemijahan/spawning Ground }\end{array}$ & $24(63 \%)$ & & 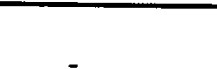 \\
\hline - Daerah pengasuhan/Nursery Ground & $24(63 \%)$ & $\begin{array}{l}14(37 \%) \\
14(37 \%)\end{array}$ & - \\
\hline $\begin{array}{l}\text { - Daerah untuk bergerak bebas /Roaming } \\
\text { site }\end{array}$ & $38(100 \%)$ & & 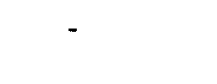 \\
\hline $\begin{array}{l}\text { - D. tempat mencari makan /Feeding } \\
\text { ground }\end{array}$ & $38(100 \%)$ & - & - \\
\hline $\begin{array}{l}\text { - Daerah tempat berlindung /Refuge Site } \\
\text { Dominasi Pemerintah }(n=22) \text { /State-Run } \\
\text { Management }\end{array}$ & $12(31 \%)$ & $26(69 \%)$ & - \\
\hline - Daerah pemijahan/spawning ground) & $10(45 \%)$ & $8(36 \%)$ & $4(18 \%)$ \\
\hline - Daerah pengasuhan/Nursery Ground & $10(45 \%)$ & $6(27 \%)$ & $6(27 \%)$ \\
\hline $\begin{array}{l}\text { - Daerah untuk bergerak bebas Roaming } \\
\text { site }\end{array}$ & $20(91 \%)$ & $2(9 \%)$ & 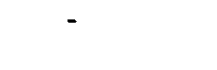 \\
\hline $\begin{array}{l}\text { - Daerah tempat mencari makan /Feeding } \\
\text { ground }\end{array}$ & $16(73 \%)$ & $6(27 \%)$ & - \\
\hline - Daerah tempat berlindung IRefuge Site & $14(64 \%)$ & $6(27 \%)$ & $2(9 \%)$ \\
\hline
\end{tabular}

manajemen dan pola pengelolaan yang keberadaan keadaan yang memberikan dukungan bagi siklus kehidupan ikan baik untuk spawning ground (daerah pemijahan), nursery ground (daerah untuk pengasuhan), roaming site (daerah untuk bergerak bebas), feeding ground (daerah untuk tempat mencari makan), dan refuge site (daerah untuk tempat berlindung), seperti yang digambarkan pada Tabel 6. masyarakat nelayan, tetapi juga termasuk pedagang, masyarakat desa sekitar dan pemerintah daerah setempat (desa dan ataupun kabupaten). Mereka juga menganggap penting keberadaan kelompok kerja pengelolaan sumberdaya perikanan dimana didalamnya termasuk pengelolaan suaka perikanan dalam suatu pertemuan yang dilakukan oleh kelompok kerja yang mengikutsertakan perwakilan dari masyarakat 
nelayan. Mereka juga sangat menyadari dan merasa sangat bertanggung jawab dalam menjaga dan memelihara suaka perikanan yang ada di desa atau perairan tempat mereka melaksanakan penangkapan ikan.

Disamping itu memiiki motivasi yang sebenarnya merupakan dorongan untuk turut serta menjaga dan memelihara suaka perikanan.

Pada perairan umum yang menerapkan suaka perikanan dengan pola pengelolaan yang didominasi oleh pemerintah, sebesar $36 \%$ masyarakat nelayannya tidak mempunyai motivasi untuk menjaga dan memelihara suaka perikanan. Dalam hal ini mereka tetap berpendapat bahwa mengelola suaka perikanan merupakan tugas dan kewajiban pemerintah. Dalam pola komanajemen terdapat pengakuan terhadap hak hukum tradisional tetapi pada perairan umum yang pengelolaannya didominasi pemerintah sebagian besar atau sebesar $72 \%$ masyarakat nelayan menyatakan tidak terdapat pengakuan terhadap hak hukum tradisional.

Pada perairan umum yang menerapkan suaka perikanan dengan pola ko-manajemen maupun dengan pola pengelolaan yang didominasi oleh pemerintah sama-sama terdapat ukuran individu ikan yang mengecil untuk 7 (tujuh) jenis ikan yang sama. Kemudian, sama-sama terdapat penurunan produktivitas hasil tangkapan nelayan, tetapi kondisi penurunan drastis terdapat pada perairan umum yang pengelolaannya didominasi oleh pemerintah. Namun untuk daerah pemijahan, $18 \%$ nelayan menyatakan sedikit pada perairan yang suaka perikanannya dikelola dengan pola yang didominasi oleh pemerintah. Begitu pula untuk daerah asuhan dan daerah untuk tempat berlindung.

\section{DAFTAR PUSTAKA}

Anonymous. 2000. Panduan Pengelolaan Bersama Suaka Penangkapan Ikan di Perairan Sungai dan Rawa Banjiran. Pusat Penelitian dan Pengembangan Perikanan bekerja sama dengan Marine Resource Assesment Group (MRAG). Jakarta. 27 p.

Blase, M.G., 1971. Role of institutions in agricultural development: In Blase M.G. (ed); Institutions Agricultural Development. The lowa State University Press. Iowa. p.3-13
Braun, J.V. and Felbrudge, T. 1998. Institutional aspects of the handling of crises and disasters in developing countries. ECONOMICS. Vol. 57 Institute for Scientific Co-operation. Tubingen. Federal Republic of Germany. p. 95-113.

Dahuri, R., Kusumastanto, T., Zamani, N.P., Kinseng, R.A., Adrianto, L., dan Wahyu. N. 1998. Penyusunan Konsep Pengelolaan Sumberdaya Pesisir dan Lautan yang Berakar pada Masyarakat. Laporan Akhir. Kerjasama Direktorat Jenderan Pembangunan Daerah, Departemen Dalam Negeri dengan Pusat Kajian Sumberdaya Pesisir dan Lautan, Institut Pertanian Bogor. $137 \mathrm{p}$.

Eckhardt, K.W. and Ermann. M.D. 1977. Social Research Methods; Perpecstive, Theory and Analysis. Random Haouse. New York. 412 p.

Goode, W.J. dan Hatt. P.K. 1986. Metode-Metode Penelitian Sosial. Disadur Oleh: Imam Munawir Penerbit Usaha Nasional. Surabaya.

Goldsmith, A.A. and Brikerhoff, D.W. 1990. Sustainability and rural and agricultural development. In Brinkerhoff D.W. and Goldsmith A.A. (eds); Institutional Sustainability in Agricultural and Rural Development; A Global Perpecstive. Praeger Publisher. New York. p.718.

Hartwick, J.M., and Olewiler, N.D. 1986. The Economics of Natural Resource Use. Harper \& Row Publisher, New York.

Hoggarth, D.D., Cowan, V.J., Halls, A.S., AeronThomas, M., McGregor, J.A., Garaway, C.A., Payne, A.I., and Welcomme, R.L. 1999. Management guidelines for Asian floodplain river fisheries. Part 1: A spatial, hierarchical and integrated strategy for adaptive comanagement. FAO Fisheries Technical Paper. $384 / 1$. Food and Agriculture Organization of the United Nations. Rome. 63 p.

Israel, A., 1987. Institutional Development; Incentive to Performance. The John Hopkins University Press. Baltimore and London. $214 \mathrm{p}$.

Johnson, G.L. 1986. Research Methodology for Economists: Philosolhy and Practice. MacMillan Publishing Company. New York. 252 p.

Luykx, N. 1971. Rural Governing Institutions: In Blasé, M.G. (ed); Institutions Agricultural Development. The lowa State University Press. lowa. p. 3-13

Mellquist, P., 1992. River Management-Objectives and Applications. In. Boon, P.J., Calow, P. and Petts G.E. (eds); River Conservation and Management, John Wiley \& Son. ChichesterNew York-Singapore. p. 1-8

Nazir, M. 1988. Metode Penelitian. Penerbit Ghalia Indonesia. Jakarta. 622 p.

Pakpahan, A. 1989. kerangka analitik untuk penelitian rekayasa sosial: persfektif ekonomi institusi. In Pasandaran E. et a: (eds); Prosiding Patanas Evolusi Kelembagaan Pedesaan di 
Tengah Perkembangan Teknologi Pertanian. Pusat Penelitian Agro Ekonomi. Badan Litbang Pertanian. Departemen Pertanian. Jakarta. p. 1-18.

Pollnac, R.B., 1988. Karakter sosial dan budaya dalam pengembangan perikanan berskala kecil. In Cernea, M.M. (ed.); Mengutamakan Manusia di Dalam Pembangunan; Variabel-variabel Sosiologi di Dalam Pembangunan Pedesaan. Penerbit Universitas Indonesia. Jakarta.

Pomeroy, R.S. 1991. Toward a community based approach to small-scale fisheries management and development. In Poggie, J.J. \& Pollnac, R.B. (eds); Small-Scale Fishery Development: Sociocultural Persfectives: International Center for Marine Resource Development (ICRMD), University of Rhode Island. Kingston, Rhode island. U.S.A.

Pomeroy, R. S., 1993. A Research Framework for
Coastal Fisheries Co-Management Institutions. NAGA. The ICLARM Quartenly. Januari 1993.

Pomeroy, R.S., and M. J. Williams. 1994. Fisheries Co-management and Smallscale Fisheries: A Policy Brief. ICLARM. Manila. 15 p.

Rettig, R.B., F. Berkes. and E. Pinkerton, 1989. The Future of Fisheries Co-Management: $A$ Multi-Disciplinary Assessment. In. E. Pinkerton (ed): Co-Operative Management of Local Fisheries. New Direction for Improved Management and Community Development. University of British Columbia Press. Vancover. p. 273-289

Troadec, J.P., 1992. Introduction to fisheries management; advantages, difficulties and mechanisms. FAO Fisheries Technical Paper 224, Food and Agriculture Organization of the United Nations. Rome. 57 p. 